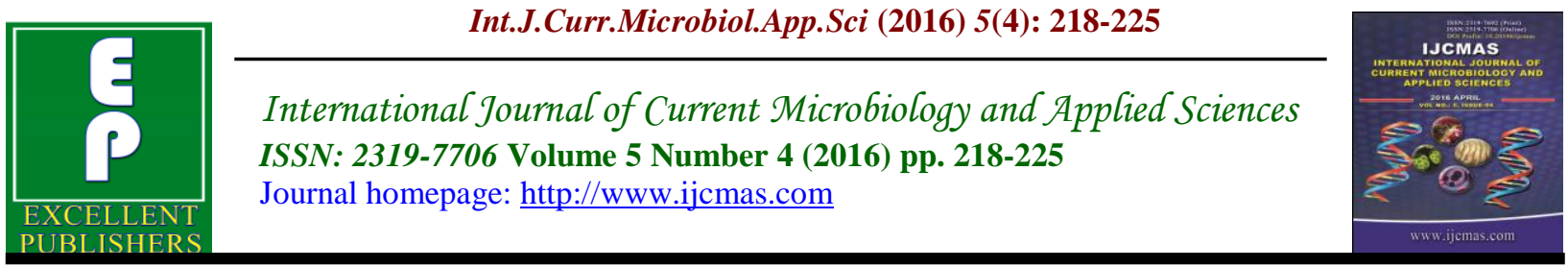

Original Research Article

http://dx.doi.org/10.20546/ijcmas.2016.504.027

\title{
Determination of L-Glutaminase Activity by Some Bacterial Species
}

\author{
Gulbahar F. Karim ${ }^{1}$ and Karkaz M. Thalij ${ }^{2 *}$ \\ ${ }^{1}$ College of Nursing-University of Kirkuk-Iraq \\ ${ }^{2}$ Department of Food Sciences-University of Tikrit-Iraq \\ *Corresponding author
}

\begin{abstract}
A B S T R A C T
Keywords

L-glutaminase, Production, E. coli and Pseudomonas aerogenosa.

\begin{tabular}{l}
\hline Article Info \\
\hline Accepted: \\
15 March 2016 \\
Available Online: \\
10 April 2016
\end{tabular}

Out of 200 clinical samples, 178(89\%) bacterial isolates were recovered. Based on, cultural, morphological, and biochemical testes, there were 87 (48.88\%) isolates of Gram positive cocci belong to the genus Staphylococcus, including, 63(35.39\%) and 24(13.48\%) isolates of Staph aureus and Staph epidermidis respectively. Whereas the 91(51.12\%) remainder isolates were belong to the family Enterobacteriaceae and distributed as 56(31.46\%), 23(12.92\%) and, 12(6.74\%) isolates of E. coli, Pseudomonas aeruginosa and Citrobacter diversus respectively. All the bacterial isolates were screened for L-glutaminase enzyme activityusing rapid plate assay. Twenty six $(14.61 \%)$ isolates were found to be L-glutaminase producers. The zone index was calculated for all L-glutaminase producing samples which are ranged from (3.0-0.25). The maximum zone index was recorded by Pseudomonas aerogenosa. The enzymatic activity were ranged from(18.56.9)IU/ml. However the maximum activity was recorded for E. coli. No.7, Hence this isolate was selected to produce large scale from the L-glutaminase enzyme for further investigations.
\end{abstract}

\section{Introduction}

Microbial enzymes play a major role in the diagnosis, curing, biochemical investigation, and monitoring of many diseases. Microorganisms represent an excellent source of many therapeutic enzymes owing to their broad biochemical diversity and their susceptibility to genetic manipulation. The manufacture of enzymes for use as drugs is an important facet of today's pharmaceutical industry (Saptarshi and Lele, 2011). Biomedical sciences accentuate the involvement of the enzyme L-Glutaminase and other amino acid depleting enzymes as a therapeutic agents for the treatment of tumor
(Holcenberg, 1982). L-Glutaminase (Lglutamine amidohydrolase E.C 3.5.1.2) is a hydrolytic enzyme that deaminates Lglutamine to glutamic acid and ammonia (Roberts et al., 1970). Another application of L-glutaminase in food flavoring especially in the soy souse and related industries of the orient.

With the development of biotechnology, microbial glutaminase found newer application in clinical analysis and even in manufacture of metabolites. It uses in biosensors for monitoring glutamine levels 
in mammalian and hybridoma cell cultures without the need of separate measurement of glutamic acid (Sabu et al., 2002). Many microorganisms, such as bacteria, yeasts, moulds and filamentous fungi, have been reported to produce L-glutaminase.

This enzyme from microbial origin supposed to be more stable than that from animal and plant sources (Sajitha et al., 2013). Commercial production of glutaminase is carried out using submerged fermentation $(\mathrm{SmF})$ technique. Also solid state fermentation (SSF) has emerged as a promising technology for the development of several bioprocesses which include the production of industrial enzymes on a large scale (Athira et al., 2014). The main objective of this study is to investigate the production and determined the Lglutaminase activity by some clinical bacterial species.

\section{Materials and Methods}

\section{Sample Collection, Isolation, and Identification of Isolates}

Two hundred Samples are collected from in and out patients with wound infections admitted to the Sulaimani Teaching Hospital during the period from March 2014 to December 2014. The samples were collected using disposable sterile swabs, they transferred immediately to the laboratories for culturing in Brain heart infusion broth, on Blood agar, Nutrient agar and MacConkey agar, then incubated at $37^{\circ} \mathrm{C}$ for 24 hours. There were 178 samples yield positive growth. Colonies are purified and used for identification tests. All bacterial isolates were examined by biochemical tests according to Bergey's manual of determinative bacteriology (Holt et al., 1994). The results were confirmed by performing Vitek technique. The culture was maintained on Nutrient agar medium slants.
Inoculated slants were grown in an incubator at $37{ }^{\circ} \mathrm{C}$ for $24 \mathrm{hr}$. After that the slants were stored at $4{ }^{\circ} \mathrm{C}$ in a refrigerator for short term preservation and sub cultured every 15 days in the abovementioned medium.

Qualitative production of L-glutaminase Enzyme (Screening Test, Rapid Plate Assay)

The minimal agar media $(\mathrm{g} / \mathrm{l}$ of distilled water) contains $\mathrm{NaCl}, \quad 0.5 ; \quad \mathrm{KCl}, \quad 0.5$; $\mathrm{MgSO} 4.7 \mathrm{H} 2 \mathrm{O}, \quad 0.5 ; \quad \mathrm{KH} 2 \mathrm{PO} 4$, 1; FeSO47H2O, 0.1; $\mathrm{ZnSO} 47 \mathrm{H} 2 \mathrm{O}, \quad$; Lglutamine, 0.5: as nitrogen source, and supplemented with $2.5 \%$ phenol red dye (prepared in ethanol and the $\mathrm{pH}$ was adjusted to 7.0). Control plate was maintained without glutamine (instead containing $\mathrm{NaNO} 3$ as nitrogen source). After autoclaving, the prepared media were inoculated with $24 \mathrm{hr}$. old bacterial colonies then incubated at $37^{\circ} \mathrm{C}$ for $24 \mathrm{hr}$. The pink zone around bacterial colonies were observed, and the zone index was calculated according to (Gulati et al., 1997).

Zone index $=$ Diameter of zone produced by L-Glutaminase (mm)/ Diameter of bacterial colony (mm).

\section{Inoculum Preparation}

The inoculum for all L-glutaminase producing isolates were prepared in $250 \mathrm{ml}$ Erlenmeyer flasks containing $100 \mathrm{ml}$ of above medium at $\mathrm{pH}$ 7.0. The medium was autoclaved at $121{ }^{\circ} \mathrm{C}(15 \mathrm{lb})$ for $15 \mathrm{~min}$., then inoculated with the bacterial isolate. The inoculated flasks were kept on a shaker at $150 \mathrm{rpm}$ for $24 \mathrm{hrs}$, then used as an inoculums.

\section{Quantitative Production of L-glutaminase Enzyme (Large Scale)}

The L-Glutaminase production medium 
(GPM) was prepared according to Suresh Kumar, et.al. (Suresh Kumar et al., 2013) with slight modification. The medium composed of ( $\mathrm{g} / \mathrm{l}$ of distilledwater): Galactose 10.0, Yeast extract 10.0, LGlutamine 10.0, Magnesium sulphate 0.5, KH2PO4 0.5, K2HPO4 0.5, NaCl 10. These components were dissolved and the volume was made up to $1 \mathrm{~L}$ with D.W. then each 100 $\mathrm{ml}$ dispensed in $250 \mathrm{ml}$ Erlenmeyer flasks, autoclaved at $121^{\circ} \mathrm{C}(15 \mathrm{lb})$ for $30 \mathrm{~min}$. , then they were aseptically inoculated with $3 \%$ of the prepared inoculum from Glutaminase producing isolates and incubated at $37^{\circ} \mathrm{C}$ for $24 \mathrm{hrs}$. at $150 \mathrm{rpm}$ in shaker incubator.

The bacterial cells are harvested in refrigerated centrifuge at $8000 \mathrm{rpm}$ for 20 min at $4{ }^{\circ} \mathrm{C}$. The supernatant was used for enzymatic assay, and the cells washed twice with $0.02 \mathrm{M}$ phosphate buffer $\mathrm{PH}$ 8. Then the cells were disrupted by ultra sonication (Soniprep 150 sonicator) for $5 \mathrm{~min}$. (intermittent) under cold conditions (Scopes, 1987). The supernatant was the source of crud enzyme and used for further enzymatic assay procedures.

\section{Determination of Enzyme Activity}

L-Glutaminase was assayed according to (Imada et al., 1973). The reaction mixture, containing $0.5 \mathrm{ml}$ of an enzyme preparation, $0.5 \mathrm{ml}$ of L-glutamine $(0.04 \mathrm{M})$,

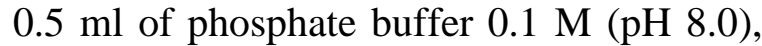
and $0.5 \mathrm{ml}$ of distilled water to a total volume of $2 \mathrm{ml}$ solution was incubated at $37^{\circ} \mathrm{C}$ for $30 \mathrm{~min}$. The reaction was stopped by addition of $0.5 \mathrm{ml}$ of $1.5 \mathrm{M}$ Trichloro acetic acid. Then to $3.7 \mathrm{ml}$ of distilled water, $0.1 \mathrm{ml}$ of the above mixture and $0.2 \mathrm{ml}$ of Nessler's reagent were added and color developed was read after keeping the mixture at $20^{\circ} \mathrm{C}$ for $20 \mathrm{~min}$ at $450 \mathrm{~nm}$ in a spectrophotometer. Enzyme and substrate blanks were used as controls. One unit of L-
Glutaminase activity was defined as the amount of enzyme that liberated $1 \mu \mathrm{mol}$ of ammonia per one minute under optimal assay conditions. Assays were done in triplicate and the mean enzyme activity was expressed as International unit per $\mathrm{ml}$ (IU/ml).

\section{Results and Discussion}

\section{Isolation and Identification of Bacteria}

From 178wound samples which yielded positive growth, there were $87(48.88 \%)$ isolates of Gram positive cocci belong to the genus Staphylococcus, including, $63(35.39 \%)$ and 24(13.48\%) isolates of Staph. aureus and Staph epidermidis respectively. Whereas the 91(51.12\%) remainder isolates were belong to the family Enterobacteriaceae and distributed as $56(31.46 \%), 23(12.92 \%)$ and, 12(6.74\%) isolates of E. coli, Pseudo aerogenosa, and Citrobacter diversus respectively as revealed in Table 1. These results depended on morphological characteristics of bacterial isolates on cultural media and Gram staining as well as to the results obtained from conventional biochemical tests as represented in Table 2. and Table 3. The diagnosis of these bacterial species were confirmed by performing Vitek technique.

\section{Qualitative Estimation of L-glutaminase Activity}

All the bacterial isolates were submitted to the screening test for producing Lglutaminase enzyme which carried out by rapid plate assay (Gulati et al., 1997).

Out of $178(89 \%)$ screened isolates, 26 $(14.61 \%)$ bacteria were able to form pink zone in plates, Characteristics of Lglutaminase producing bacteria. The bacterial L-glutaminase hydrolysed L- 
glutamine to glutamate and ammonia. The acid base indicator dye phenol red converts in to pink colour at basic PH.The zone index was calculated for all L-glutaminase producing samples which are ranged from (3.0 -0.25) as presented in (Table 4).

The maximum zone index was recorded by Pseudo. aeruginosa, whereas the minimum zone index was for six isolate of E.coli. Three isolates of Pseudo. aeruginosa had zone index of 2.75, while zone index of 2 was recorded for four isolates of Staph aureus, followed by zone index of 1.75 that recorded for two isolates of Staph. epidermidis.

The zone index of 1.5 was recorded for three isolates of Staph aureus and two isolates of Staph. epidermidis. Where as zone index of 1.25 was recorded for two isolates of Citrobacter diversus and zone index of 1 was recorded for one isolate of Citrobacter diversus. Ultimately the zone index of 0.5 was recorded for one isolates of E.coli.

Many researchers were investigated the production of L-glutaminase from varies microbial origins, including bacteria as Staph. Aureus, Pseudo. aeruginosa (Soda et al., 1972; Oshima et al., 1976; Rashmi et al.,
2012), E.coli (Pruisner et al., 1976), yeast and filamentous fungi(Elshafei et al., 2014). The production titer value of these enzymes are influenced by microbial strains and fermentation conditions (Iyer and Singhal, 2008).

\section{Quantitative Estimation of L-glutaminase Activity}

All the 26 Positive isolates which were screened for L-glutaminase in the above step were further cultured in Glutaminase producing media (GPM) containing Lglutamine as a sole carbon and nitrogen source. Quantitative estimating of Lglutaminase activity by selective isolates was carried out using Nesslerization process. The enzymatic activity were ranged from (18.5-6.9) as shown in table 4.6.

However the maximum activity was recorded for E. coli. No.7 despite the narrow zone index that produce by this bacteria in the previous step, this finding might be attributed to intracellular production of the enzyme by this bacteria (Hartman, 1968). Hence this isolate was selected to produce large scale from the enzyme L-glutaminase for further study.

Table.1 Distribution of Bacterial Isolates from Wounds Infections

\begin{tabular}{|c|c|c|c|c|c|c|}
\hline $\begin{array}{l}\text { Source } \\
\text { of } \\
\text { isolates }\end{array}$ & $\begin{array}{l}\text { Staph. } \\
\text { aureus }\end{array}$ & E. coli & $\begin{array}{c}P . \\
\text { aeruginosa }\end{array}$ & $\begin{array}{c}\text { Staph } \\
\text { epidermis }\end{array}$ & $\begin{array}{c}\text { Citr. } \\
\text { diversus }\end{array}$ & $\begin{array}{c}\text { Total } \\
\text { isolates }\end{array}$ \\
\hline $\begin{array}{l}\text { Infected } \\
\text { Wounds }\end{array}$ & 63 & 56 & 23 & 24 & 12 & 178 \\
\hline$(\%)$ & 35.39 & 31.46 & 12.92 & 13.48 & 6.74 & 100 \\
\hline
\end{tabular}


Table.2 Type of Tests for Staph aureus and Staph epidermidis Identifications

\begin{tabular}{|l|c|c|}
\hline \multicolumn{1}{|c|}{ Identification tests } & Staph. aureus & Staph epidermidis \\
\hline Gram stain & + & + \\
\hline Motile tests & - & - \\
\hline Catalase test & + & + \\
\hline Oxidase test & - & - \\
\hline Mannitol salt fermentation & + & - \\
\hline Coagulase test & + & + \\
\hline $\begin{array}{l}\text { Type of Haemolysis on } \\
\text { bloodagar }\end{array}$ & $\boldsymbol{\beta}$. Type & \\
\hline
\end{tabular}

Table.3 Biochemical Tests for Identification of E. coli, P. aeruginosa and C. diversus isolates

\begin{tabular}{|c|c|c|c|c|}
\hline & "Biochemical test & E. coli & P. aeruginosa & C. diversus \\
\hline \multicolumn{2}{|r|}{ Indole } & + & - & + \\
\hline \multicolumn{2}{|r|}{ Methyl red } & + & _ & + \\
\hline \multicolumn{2}{|r|}{ Voges proskauer } & - & _ & - \\
\hline \multicolumn{2}{|r|}{ Citrate utilization } & - & + & + \\
\hline \multicolumn{2}{|r|}{ Urease production } & - & + & $\mathbf{V}$ \\
\hline \multicolumn{2}{|r|}{ Oxidase } & - & + & - \\
\hline \multicolumn{2}{|r|}{ Catalase } & + & + & \\
\hline 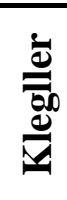 & $\begin{array}{l}\text { Gas production } \\
\text { H2S production } \\
\text { Slope } \\
\text { Bottom }\end{array}$ & $\begin{array}{c}+ \\
- \\
\text { Acid } \\
\text { Acid }\end{array}$ & $\begin{array}{c}++ \\
+ \\
\text { Alkaline } \\
\text { Alkaline }\end{array}$ & $\begin{array}{c}\mathrm{V} \\
\overline{-} \\
\text { Acid } \\
\text { Acid }\end{array}$ \\
\hline \multicolumn{2}{|r|}{ Motility } & + & + & + \\
\hline
\end{tabular}

Table.4 Ability of Bacterial Isolates to Production of L- Glutaminase

\begin{tabular}{|c|c|c|c|}
\hline $\begin{array}{c}\text { Isolates species and } \\
\text { number. * }\end{array}$ & $\begin{array}{c}\text { Total } \\
\text { isolates } \\
\text { counts }\end{array}$ & Isolates No. & $\begin{array}{c}\text { Glutaminase } \\
\text { production assay } \\
\text { (Zone index) }\end{array}$ \\
\hline \multirow{2}{*}{ Staphylococcus aureus } & \multirow[b]{2}{*}{63} & $7,14,42,56$ & 2.0 \\
\hline & & $15,27,51$ & 1.5 \\
\hline \multirow{2}{*}{$\begin{array}{c}\text { Staphylococcus } \\
\text { epidermis }\end{array}$} & \multirow{2}{*}{24} & 5,12 & 1.75 \\
\hline & & 16,23 & 1.5 \\
\hline $\begin{array}{c}\text { Pseudomonas } \\
\text { aeruginosa }\end{array}$ & 23 & $\begin{array}{c}15,23 \\
1,9,20 \\
\end{array}$ & $\begin{array}{c}3.0 \\
2.75 \\
\end{array}$ \\
\hline \multirow{2}{*}{ Escherichia coli } & \multirow{2}{*}{56} & 7 & 0.5 \\
\hline & & $3,27,40,52,22,37$ & 0.25 \\
\hline \multirow{2}{*}{ Citrobacter diversus } & \multirow{2}{*}{12} & 1,8 & 1.25 \\
\hline & & 10 & 1.0 \\
\hline
\end{tabular}

* Bacterial isolates numbers that's not mention means not produced L-glutaminase 
Table.4-6 L-Glutaminase Activity (IU/Ml) for Bacterial Isolates from Wounds Source

\begin{tabular}{|c|c|c|}
\hline Isolates species and number. $*$ & Isolates No. & $\begin{array}{c}\text { Glutaminase activity } \\
\text { (IU/ml) }\end{array}$ \\
\hline \multirow{2}{*}{ Staphylococcus aureus } & $7,14,42,56$ & 12.43 to 18.26 \\
\cline { 2 - 3 } & $15,27,51$ & 8.6 to 10.7 \\
\hline \multirow{2}{*}{ Staphylococcus epidermis } & 5,12 & $11.5,12.2$ \\
\cline { 2 - 3 } Pseudomonas aeruginosa & 16,23 & $6.9,8.5$ \\
& 15,23 & $12.3,14.0$ \\
\cline { 2 - 3 } & $1,9,20$ & 8.5 to 11.7 \\
Escherichia coli & 7 & 18.5 \\
\hline & $3,27,40,52$ & 11.0 to 14.3 \\
\cline { 2 - 3 } & 22,37 & $7.2,9.4$ \\
\hline Citrobacter diversus & 1,8 & $10.0,13.8$ \\
\hline
\end{tabular}

* Bacterial isolates numbers that's not mention means not produced L-glutaminase

L-glutaminase have been reported in many microbial species but their biochemical, and enzymatic, substrate specificity, molecular weight and antitumor activities vary with genetic nature and cultural conditions which optimized by investigators for various microorganisms as for filamentous fungi by (Nathiya et al., 2012). The enzyme activity for E.coli estimated by (Hughesd and Williamsodn, 1952), the optimum activity of the L-glutaminase $\mathrm{A}$ and $\mathrm{B}$ which produce by E.coli depends on PH, Glutaminase A have optimal activity at $\mathrm{PH}$ about 5, such enzyme would be unsuitable for clinical application where they would be required to be use at $\mathrm{PH}$ above 7 as that used by (Roberts et al., 1970). Whereas the glutaminase $\mathrm{B}$ have maximum activity at $\mathrm{pH}$ above 7 (Prusiner, 1975).

The maximum yield of L-glutaminase from Pseudomonas aeruginosa and Serratia marcescens obtained following optimization of fermentation process by (Rashmi et al., 2012). Also L-glutaminase production from aerobic gram positive filamentous bacteria Streptomyces griseus under optimized conditionwas reported by (Suresh Kumar et al., 2013). With maximum activity of 45IU/ml. However, Tullimilli et.al.
(Tullimilli et al., 2014), reported the maximum activity of L-glutaminase produced by fungal strain Mucor racemosus at $969.23 \mathrm{IU} / \mathrm{mlafter}$ optimizing culture conditions. It have been concluded from these results that E.coli No.7 has potential for large scale production of L-glutaminase enzyme for use in industrial and pharmaceutical applications.

\section{References}

Athira, R.N., Elizebeth, T., Narendra, T., Sheik Tanweer Ahmed, Shankar Kumar Gupta, Manoj Chaudary, Siddalingeshwara, K.G., Pramod, T. 2014. Investigation on the production of L-glutaminase from Pseudomonas stutzeri strain under solid state fermentation using various agro residues. J. Drug Delivery \& Therapeutics; 4(2): 81-85.

Elshafei, A.M., Hassan, M.M., Ali, N.H., Abouzeid, M.A., Mahmoud, D.A., Elghonemy, D.H. 2014. Purification, Kinetic properties and antitumor activity of L-glutaminase from Penicillium brevi compactum NRC 829. British Microbiol. Res. J., 4(1): 97-115. 
Gulati, R., Saxena, R.K., Gupta, R.A. 1997. Rapid plate assay for screening of Lasparginase producing microorganisms. Lett. Appl. Microbiol., 24: 23-26.

Hartman, S.C. 1968. Glutaminase of Escherichia coli. Purification and general catalytic properties. J. Bio. Chem., 243: 853-863.

Holcenberg, J.S. 1982. Enzyme Therapy: Problems and Solutions. Ann. Rev. Biochem., 51: 795-812.

Holt, J.G., Grieg, N.R., Sneath, P.H.A., Staley, J.T., Williams, S.T. 1994. Bergey's manual of determinative bacteriology $9^{\text {th }} \mathrm{Ed}$. Williamsons and Wilkins, Baltimore.

Hughesd, E., Williamsodn, H. 1952. Some properties of the glutaminase of Clostridium welchii. Biochem. J., 51: 45-55.

Imada, A., Igarasi, S., Nakahama, K., Isono, M. 1973. Asparginase and glutaminase activities of microorganisms. J. Gen. Microbiol., 76: 85-99.

Iyer, P., Singhal, R.S. 2008. Production of glutaminase (E.C.2.3.1.5) from Zygosaccharomyces rouxii: statistical optimization using response surface methodology. Biores. Technol., 99: 4300-4307.

Nathiya, K., Sooraj, S.N., Angayarkanni, J., Palaniswamy, M. 2012. In vitro cytotoxicity of L-Glutaminase against MCF-7 cell lines. Asian J. Pharm. Clin. Res., 5(2): 171-173.

Oshima, M., Yamamoto, T., Soda, K. 1976. Further characterization of glutaminase isozymes from Pseudomonas aeruginosa. Agri. Biol. Chem., 40: 2251-2256.

Pruisner, S., Oavis, J.N., Stadtman, E.R. 1976. Regulation of glutaminase B in E.coli. J. Biol. Chem., 251: 34473456.
Prusiner, S. 1975. Regulation of glutaminase level in Escherichia coli. J. Bacteriol., 123(3): 992-999.

Rashmi, A.M., Gopinath, S.M., Krishan kumar, Narasimha Murthy, T.P. 2012. Optimization of submerged fermentation process for Lglutaminase produced by Pseudomonas aeruginosa BGNAS-5. Int. J. of Latest Res. in Sci. and Technol., 1(4): 308-310.

Roberts, J., Holcenberg, J.S., Dolowy, W.C. 1970. Antineoplastic activity of highly purified bacterial glutaminase. Nature, 227: 1136-1137.

Sabu, A., Sukumaran, R.K., Muthusamy, C. 2002. L-glutaminase as a therapeutic enzyme of microbial origin, Methods in Biotechnology. Vol. 17, Microbial enzymes and Biotransformation, Human Press Inc.

Sajitha, N., Vasuki, S., Suja, M., Kokilam, G., Gopinath, M. 2013. Screening of L-glutaminase from Seaweed endophytic fungi. Int. Res J Pharm. App Sci., 3(5): 206-209.

Saptarshi, S.D., Lele, S.S. 2011. Localization and disruption kinetics of L-asparginase from Erwinia carotovora cells by high power ultrasound. Chem. Biochem. Eng. Q., 25: $65-73$.

Scopes, R.K. 1987. Protein purification. $2^{\text {nd }}$ ed. Springer. Velag. New York.

Soda, K., Oshima, M., Yamamoto, T. 1972. Purification and properties of isozymes of glutaminase from Pseudomonas aeruginosa. Biochemistry Biophysics Res. Communications, 46: 1278-1284.

Suresh Kumar, S., Muthuvelayudham, R., Viruthagiri, T. 2013. Medium optimization for production of LGlutaminase (E C.3.5.1.2) by Streptomyces griseus. IJSEA, 2(1): 15. 
Suresh Kumar, S., Muthuvelayudham, R., Viruthagiri, T. 2013. Statistical Optimization based Production of LGlutaminase (E C.3.5.1.2) by Serratia marcescens under submerged Fermentation. Res. J. Chem. Sci., 3(6): 43-53.
Tullimilli, A., Sankar, J, Bondili, P.B., Ramachandra, R. 2014. Studies on isolation, screening and molecular characterization of L-glutaminase producing marine isolates, IJSID, 4(1): 33-44.

\section{How to cite this article:}

Gulbahar F. Karim and Karkaz M. Thalij. 2016. Determination of L-Glutaminase Activity by Some Bacterial Species. Int.J.Curr.Microbiol.App.Sci. 5(4): 218-225.

http://dx.doi.org/10.20546/ijcmas.2016.504.027 